\title{
PENERAPAN MODEL PEMBELAJARAN KOOPERATIF TIPE TIME TOKEN UNTUK MENINGKATKAN HASIL BELAJAR FISIKA SISWA
}

Suwondo ${ }^{1}$, Astalini ${ }^{2}$, dan Darmaji ${ }^{3}$

${ }^{1,2,3}$ Program Studi Pendidikan Fisika FKIP Universitas Jambi, Jambi, Indonesia

Email: suwondoaza@gmail.com

\section{Info Artikel}

Diterima:

5 Maret 2019

Disetujui:

7 Juli 2019

Dipublikasikan:

15 Desember 2019

\begin{abstract}
Abstrak:
Penelitian ini bertujuan untuk mengetahui aktivitas dan hasil belajar melalui pembelajaran kooperatif tipe time token. Penelitian ini merupakan penelitian tindakan kelas. Subjek penelitian ini siswa kelas $\mathrm{X}_{\mathrm{E}}$ SMAN 3 Muaro Jambi. Instrument pengumpulan data menggunakan lembar observasi siswa dan guru selama kegiatan proses serta tes hasil belajar. Hasil penelitian ini menunjukkan bahwa terjadi peningkatan aktivitas siswa dari siklus I yaitu, 68,37\% menjadi 71,75\% pada siklus II dan $74,06 \%$ pada siklus III. Hasil belajar siswa pada siklus yaitu, 63,03 untuk siklus I menjadi 70,00 untuk siklus II dan 76,86 untuk siklus III. Penerapan model pembelajaran kooperatif tipe Time Token dapat meningkatkan aktivitas dan hasil belajar siswa pada materi suhu dan kalor di Kelas $\mathrm{X}_{\mathrm{E}}$ SMA Negeri 3 Muaro Jambi.
\end{abstract}

Kata kunci: Kooperatif tipe time token, Hasil belajar

\begin{abstract}
:
This research aims to determine the activity and learning outcomes through cooperative learning of time token type. This research was a classroom action research. The subject of this research student of $X_{E}$ SMAN 3 Muaro Jambi. Data collection instruments using student and teacher observation sheets during process activities as well as test learning outcomes. The results of this study showed that an increase in student activity from Cycle I was, $68.37 \%$ to $71.75 \%$ in cycle II and $74.06 \%$ in cycle III. Students 'learning results in cycles i.e., 63.03 for cycle I to 70.00 for cycle II and 76.86 for cycle III. The application of the Time Token Cooperative Learning model can increase the student's activity and learning outcomes at the temperature and heat material in the $X_{E} S M A$ Negeri 3 Muaro Jambi class.
\end{abstract}

Keywords: Cooperative time token type, learning outcomes

\section{Pendahuluan}

Kegiatan belajar dan mengajar
diarahkan untuk pembentukan mental,
penciptaan lingkungan belajar yang dapat
mempengaruhi pengembangan kognitif siswa dan membantunya agar lebih sadar terhadap proses berfikirnya, misalnya dalam hal kemampuan dasar siswa, pengetahuan, sikap dan motivasinya. Berhasil atau tidaknya pencapaian pembelajaran tidak lepas dari guru 
dalam menerapkan model dan metode yang dapat mendorong siswa untuk belajar

Berdasarkan hasil observasi di SMA Negeri 3 Muaro Jambi didapatkan bahwa aktivitas pembelajaran yang telah dilaksanakan oleh guru sudah baik. Guru telah mengusahakan agar semua siswa aktif dalam kegiatan pembelajaran. Pengunaan media pembelajaran di sekolah telah dimanfaatkan, berbagai bentuk penugasan telah diberikan untuk dikerjakan oleh siswa. Dalam proses ini (tanya jawab dan diskusi kelas) terlihat banyak siswa yang tidak aktif dalam berkomunikasi, seperti: siswa yang malu bertanya kepada guru, siswa yang diam dalam berdiskusi dan menunggu hasil dari temannya, malu mengemukakan pendapatnya dengan teman waktu diskusi, yang menjawab pertanyaan hanya siswa tertentu saja dan tidak berganti dengan siswa yang lain. Sehingga lebih banyak siswa yang tidak aktif dalam kegiatan pembelajaran. Jika hal ini terus berlanjut, maka hanya beberapa siswa saja yang nantinya akan paham dengan materi yang telah diajarkan. Berdasarkan permasalahan tersebut, maka perlu adanya peningkatan kemampuan berkomunikasi pada siswa. Dengan harapan, pada kegiatan pembelajaran siswa tidak malu lagi dalam bertanya maupun mengemukakan pendapatnya. Sehingga siswa akan memahami materi yang telah diajarkan.

Salah satu model pembelajaran yang dapat meningkatkan kemampuan berkomunikasi dan hasil belajar adalah dengan model pembelajaran kooperatif. Isjoni (2012) menyatakan bahwa pembelajaran kooperatif adalah suatu model pembelajaran dimana siswa belajar dan bekerjasama dalam kelompokkelompok kecil secara kolaboratif yang anggotanya 4-6 orang dengan struktur kelompok heterogen. Pembelajaran kooperatif memiliki beberapa tipe pembelajaran. Salah satu tipe dari model pembelajaran kooperatif adalah tipe Time Token. Model pembelajaran Time Token merupakan salah satu model pembelajaran yang dapat mendorong setiap siswa untuk dapat berpartisipasi dalam pembelajaran, sehingga dapat menghindarkan salah satu siswa untuk mendominasi atau bahkan diam sama sekali. Tujuan utama pembelajaran Time Token adalah untuk mengatasi hambatan pemerataan kesempatan yang sering mewarnai kerja kelompok. Pada Time Token disisipi adanya unsur permainan, yakni kupon belajar yang menjadi tanggung jawabnya. Aktivitas siswa meningkat dengan menggunakan metode Time Token karena siswa dituntut untuk menggunakan kupon belajarnya sampai habis.

Menurut Widodo (2009) dalam Shoimin (2014), model pembelajaran Time Token sangat tepat untuk pembelajaran struktur yang dapat digunakan untuk mengajarkan keterampilan social, untuk menghindari siswa yang mendominasi pembicaraan atau siswa yang diam sama sekali. Adapun langkahlangkah pembelajaran menurut Shoimin (2014) adalah guru menjelaskan tujuan pembelajaran. Guru mengondisikan kelas untuk melaksanakan diskusi (cooperative learning/CL). Coerative learning merupakan pembelajaran yang sesuai dengan fitrah manusia sebagai makhluk sosial yang penuh ketergantungan dengan orang lain, mempunyai tujuan dan tanggung jawab bersama, pemberian tugas, dan rasa senasib. Dengan memanfaatkan kenyataan itu, dalam belajar berkelompok secara koperatif, siswa dilatih dan dibiasakan saling berbagi pengetahuan, pengalaman, tugas, dan tanggungjawab. Kegiatan pembelajaran dengan cara berkelompok untuk bekerja sama saling menbantu mengontruksi konsep, menyelesaikan persoalan dengan anggota kelompok 4-5 orang siswa. Guru memberi tugas kepada siswa. Guru memberi sejumlah kupon berbicara dengan waktu \pm 30 detik per kupon pada tiap siswa. Guru meminta siswa menyerahkan kupon terlebih dahulu sebelum berbicara atau member komentar. Setiap tampil berbicara satu kupon. Siswa dapat tampil lagi setelah bergiliran dengan siswa lainnya. Siswa yang habis kuponnya tidak boleh berbicara lagi. Siswa yang memegang kupon harus berbicara sampai semua kupnnya habis. Demikian seterusnya sampai semua anak menyampaikan pendapatnya. Guru memberi sejumlah nilai sesuai waktu yang digunakan tiap siswa.

Langkah-langkah pembelajaran menurut Huda (2013) yaitu, sebagai berikut :

1. Guru menjelaskan tujuan pembelajaran.

2. Guru mengondisikan kelas untuk melaksanakan diskusi.

3. Guru member tugas pada siswa.

4. Guru memberi sejumlah kupon berbicara dengan waktu \pm 30 detik per kupon pada tiap siswa. 
5. Guru meminta siswa menyerahkan kupon terlebih dahulu sebelum berbicara atau member komentar. Satu kupon untuk satu kesempatan berbicara. Siswa dapat tampil lagi setelah bergiliran dengan siswa lainnya. Siswa yang habis kuponnya tidak boleh berbicara lagi. Siswa yang masih memegang kupon harus berbicara sampai semua kuponnya habis. Demikian seterusnya sampai semua anak berbicara.

6. Guru memberi sejumlah nilai berdasarkan waktu yang digunakan tiap siswa dalam berbicara.

Berikut kelebihan model pembelajaran Time Token menurut Shoimin (2014) :

1. Mendorong siswa untuk meningkatkan inisiatif dan partisipasi.

2. Siswa tidak mendominasi pembicaraan atau diam sama sekali.

3. Siswa menjadi aktif dalam kegiatan pembelajaran.

4. Meningkatkan kemampuan siswa dalam bekomunikasi (aspek berbicara).

5. Melatih siswa mengungkapan pendapatnya.

6. Menumbuhkan kebiasaan pada siswa untuk saling mendengarkan, berbagi, memberikan masukan, dan keterbukaan terhadap kritik.

7. Mengajarkan siswa untuk menghargai pendapat orang lain.

8. Guru dapat berperan untuk mengajak siswa mencari solusi bersama terhadap permasalahan yang ditemui.

9. Tidak memerlukan banyak media pembelajaran.

Adapun tujuan penelitian ini adalah untuk meningkatkan aktivitas dan Hasil Belajar Fisika setelah diterapkan Model Pembelajaran Kooperatif Tipe Time Token di Kelas $\mathrm{X}_{\mathrm{E}} \mathrm{SMA}$ Negeri 3 Muaro Jambi. Adapun hasil penelitian ini diharapkan dapat memberikan untuk melatih keterampilan berbicara siswa, sehingga siswa lebih nyaman dalam belajar materi Fisika.

\section{Metode Penelitian}

Jenis Penelitian

Jenis penelitian ini adalah penelitian tindakan kelas (classroom action research). Penelitian Tindakan Kelas (PTK) merupakan perpaduan antara tindakan (action) dan penelitian (research) yang dilakukan oleh guru di dalam kelas.

Waktu dan Tempat Penelitian

Penelitian Tindakan Kelas (PTK) ini dilaksanakan di kelas $X_{E}$ pada semester II di SMA Negeri 3 Muaro Jambi tahun ajaran 2015/2016

Target/Subjek Penelitian

Subyek dalam penelitian ini adalah siswa kelas $X_{E}$ pada semester II di SMA Negeri 3 Muaro Jambi tahun ajaran 2015/2016.

Prosedur

Penelitian ini dilaksanakan dalam 3 siklus yang terdiri dari siklus I, siklus II, dan siklus III. Dalam setiap siklus terdapat empat langkah yaitu; perencanaan ( planning), pelaksanaan Tindakan (action), Observasi dan Evaluasi serta Analisis dan Refleksi.

Data, Intrumen, dan Teknik Pengumpulan Data

Sumber data dalam penelitian ini adalah siswa kelas $X_{E}$ dan guru bidang studi fisika yang mengajar dikelas $X_{E}$. Data kualitatif, yaitu data tentang bagaimana kegiatan pembelajaran, apakah sudah sesuai dengan rencana pelaksanaan pembelajaran, data ini diperoleh dari lembar observasi aktivitas siswa dan guru tiap siklus oleh guru pengamat. Data kuantitatif adalah data tentang hasil belajar siswa berupa nilai yang diperoleh dari aspek pengetahuan di kelas $\mathrm{X}_{\mathrm{E}}$. Pengambilan data kualitatif dengan menggunakan lembar observasi aktivitas siswa, lembar observasi aktivitas guru selama kegiatan proses belajar mengajar berlangsung. Sedangkan pengambilan data kuantitatif dalam penelitian ini adalah untuk menilai aspek pengetahuan dengan cara memberikan tes berupa soal-soal kepada siswa disetiap akhir siklus, sebelum soal tes digunakan dalam penelitian, perlu dilakukan uji coba dan analisa untuk memperoleh validitas soal, tingkat kesukaran tiap butir soal, daya beda tiap butir soal, dan realibilitas tiap butir soal yang memenuhi kriteria tertentu 


\section{Teknik Analisis Data}

\section{Data Kuantitatif}

Data kuantitatif hasil belajar siswa dinilai dari aspek pengetahuan, diperoleh dari hasil pemberian tes pada tahap evaluasi diakhir siklus,analisis dengan menggunakan rumus yang dikemukakan oleh (Purwanto,2013), dengan menggunakan persamaan berikut :

$$
S=\sum\left(R-\frac{W}{n-1}\right) \times W_{t}
$$

Keterangan :

$$
\begin{aligned}
& \mathrm{S}=\text { Skor } \\
& \mathrm{R}=\text { Jumlah jawaban yang benar } \\
& \mathrm{W}=\text { Jumlah jawaban yang salah } \\
& W_{t}=\text { Bobot } \\
& \mathrm{n}=\text { jumlah option (banyaknya } \\
& \text { pilihan jawaban) }
\end{aligned}
$$

Nilai rata - rata kelas dihitung dengan menggunakan persamaan yang dikemukakan oleh Sudjana (1992), sebagai berikut :

$$
\bar{x}=\frac{\sum N a}{N}
$$

Keterangan :

$$
\begin{aligned}
& \bar{x}=\text { Nilai rata }- \text { rata } \\
& \mathrm{Na}=\text { Jumlah nilai ulangan } \\
& \quad \text { siswa } \\
& \mathrm{N}=\text { Jumlah Siswa keseluruhan }
\end{aligned}
$$

Untuk menghitung persentase tingkat keberhasilan belajar digunakan persamaan yang dikemukakan oleh Arikunto (2009) sebagai berikut :

$$
\text { Nilai }=\frac{\text { Skor }}{\text { Skor maksimum }} \times 100 \%
$$

\section{Data Kualitatif}

Data kualitatif diambil dari data hasil observasi tentang situasi belajar mengajar, yaitu untuk data hasil observasi aktivitas siswa dihitung dengan menggunakan persamaan :

$$
A=\frac{N a}{N} \times 100 \%
$$

Keterangan :

$$
\begin{aligned}
& \mathrm{A}=\text { Aktifitas siswa } \\
& \mathrm{Na}=\text { Jumlah siswa yang aktif } \\
& \mathrm{N}=\text { Jumlah siswa keseluruhan }
\end{aligned}
$$

Dengan perhitungan penilaiannya sebagai berikut :

$$
\begin{aligned}
& 0-20=\text { Tidak Aktif } \\
& 21-40=\text { Kurang Aktif } \\
& 41-60=\text { Cukup Aktif } \\
& 61-80=\text { Aktif } \\
& 81-100=\text { Sangat Aktif }
\end{aligned}
$$

Untuk lembar observasi siswa ditentukan angka rata - ratanya kemudian dicocokkan dengan kategori. Angka - angka tersebut digunakan sebagai tolak ukur yang menunjukkan kualitas siswa selama proses pembelajaran. Sedangkan data untuk hasil lembaran observasi guru dihitung dengan menjumlahkan seluruh data sesuai dengan kriteria yang telah ditentukan. Siswa dikatakan sudah aktif, jika nilai rata-rata aktivitas siswa sudah mencapai nilai $60 \%$.

Instrumen Penelitian

Validitas

Suatu instrumen yang valid atau sahih mempunyai validitas tinggr. Sebaliknya, instrumen yang kurang valid berarti memiliki validitas rendah. Sebuah instrumen dikatakan valid apabila mampu mengukur apa yang diinginkan. Sebuah instrumen dikatakan valis apabila dapat mengungkap data dari variabel yang diteliti secara tetap. Tinggi rendahnya validitas instrumen menunjukkan sejauh mana data yang terkumpul tidak menyimpang dari gambaran tentang validitas yang dimaksud (Arikunto, 2010).

\section{Tingkat Kesukaran}

Tingkat kesukaran adalah peluang untuk menjawab benar suatu soal pada tingkat kemampuan tertentu(3yảng biasanya dalam bentuk indeks. Makin besar harga indeks kesukaran berarti soal itu semakin mudah atau sebaliknya. Dengan kata lain, suatu butir soal yang baik adalah soal yang tidak terlalu sukar dan tidak terlalu mudah. Setiap butir soal memiliki tingkat kesukaran yang berbeda-beda.

Untuk menetukan indeks kesukaran dapat digunakan rumus yamg 4 )dikemukakann oleh (Arikunto, 2013) yaitu: 
$P=\frac{B}{J S}$

Keterangan :

$\mathrm{P}=$ Indeks kesukaran (difficulty index)

$\mathrm{B}=$ Banyaknya siswa yang menjawab soal dengan benar

$I_{s}=$ jumlah seluruh peserta tes

Untuk mengetahui besarnya indeks kesukaran, kriteria yang digunakan adalah

$0,00<\mathrm{P} \leq 0,30=$ soal sukar

$0,31<\mathrm{P} \leq 0,70=$ soal sedang

$0,71<\mathrm{P} \leq 1,00=$ soal mudah

Indeks kesukaran ini menunjukkan tingkat kesukaran soal. Soal dengan indeks kesukaran 0,00 itu menunjukkan soal terlalu sukar, sedangkan indeks kesukaran 1,00 itu menunjukan soal terlalu mudah. Perhitungan indeks tingkat kesukaran ini dilakukan untuk setiap nomor soal. Pada prinsipnya, skor ratarata yang diperoleh siswa pada butir soal yang bersangkutan dinamakan tingkat kesukaran butir soal itu.

Daya Beda

Daya pembeda soal adalah kemampuan soal untuk membedakan antara siswa yang berkemampuan tinggi dengan siswa yang berkemampuan rendah. Daya pembeda soal dapat ditentukan dengan menggunakan persamaan yang dikemukan oleh (Arikunto,2013) yaitu :

$$
D=\frac{B A}{J A}-\frac{B B}{J B}
$$

Keterangan :

$\mathrm{D}=$ Daya beda

$\mathrm{BA}=$ Banyaknya kelompok atas menjawab soal dengan benar

$\mathrm{BB}=$ Banyaknya kelompok bawah menjawab soal dengan benar

$\mathrm{JA}=$ Jumlah siswa kelompok atas

$\mathrm{JB}=$ Jumlah siswa kelompok bawah

Besarnya daya pembeda ini berkisar antara 0,00 sampai 1,00 dan mengenal tanda negatif (-), dengan ketentuan:
D : $0,00-0,20$ : jelek
D : $0,21-0,40$ : cukup
D : $0,41-0,70$ : baik
D : $0,71-1,00$ : baik sekali

Jika nilai daya (3.5) maka soal tersebut tidaklayak digunakan atau dibuang. Begitu juga sebaliknya, jika daya pembeda soal-soal tersebut bernilai positif maka soal tersebut layak digunakan untuk tes selanjutnya.

Reliabilitas

Reliabilitas tes menunjukkan apakah suatu tes dapat mempunyai taraf kepercayaan yang tinggi jika tes tersebut dapat menghasilkan tes yang tetap. Sugiyono (2008) mengatakan bahwa instrumen yang reliabel adalah instrumen yang bila digunakan beberapa kali untuk mengukur objek yang sama, akan menghasilkan data yang sama. Sejalan dengan pendapat diatas Arikunto (2009) mengungkapkan bahwa " Reliabilitas adalah ketetapan suatu tes apabila diteskan pada objek yang sama, untuk mengetahui ketetapan ini pada dasarnya dilihat dari kesejajaran hasil".

Untuk menentukan reliabilitas dalam penelitian ini digunakan rumus KuderRichardson (K-R21) yang dikemukakan oleh Arikunto (2013) yaitu:

$r_{11}=\left(\frac{n}{n-1}\right)\left(1-\frac{M(n-M)}{n S_{t}^{n}}\right)$

$S_{t}^{2}=\frac{\Sigma X^{2}-\frac{(\Sigma X)^{2}}{N}}{N}$

$M=\frac{\Sigma X}{N}$

Keterangan :

$r_{11}=$ Reliabilitas tes soal secara keseluruhan

$\mathrm{N}=$ Banyaknya butir soal

$\mathrm{M}=$ Mean/rata-rata skor total

$\mathrm{X}=$ jumlah skor yang dijawab benar oleh siswa

$\mathrm{N}=$ jumlah peserta tes

$S_{t}^{2}=$ Varians total

$\Sigma X^{2}=$ Jumlah skor total yang dikuadratkan

$(\Sigma X)^{2}=$ Nilai pengkuadratan jumlah skor total.

Koefisien reliabilitas tes berkisar antara 0,00-

1,00 dengan perincian korelasi:

$0,00<\mathrm{r}_{11} \leq 0,20=$ sangat rendah

$0,20<\mathrm{r}_{11} \leq 0,40=$ rendah 


$$
\begin{aligned}
& 0,40<\mathrm{r}_{11} \leq 0,60=\text { cukup } \\
& 0,60<\mathrm{r}_{11} \leq 0,80=\text { tinggi } \\
& 0,80<\mathrm{r}_{11} \leq 1,00=\text { sangat tinggi }
\end{aligned}
$$

\section{Indikator Kerja}

Indikator pencapaian yang digunakan untuk mengetahui keberhasilan tindakan yang dilakukan adalah dari lembar aktivitas siswa dan dari aspek pengetahuan yang didapatkan dari siswa setiap akhir siklus. Siswa dikatakan berhasil jika telah mencapai kriteria ketuntasan minimal (KKM)

\section{Hasil Penelitian dan Pembahasan}

Siklus I merupakan pelaksanaan tindakan awal yang dilakukan pada pelaksanaan penelitian tindakan kelas ini. Pada siklus I, pelaksanaan tindakan dilakukan dua kali pertemuan dan satu kali ujian siklus. Pertemuan I membahas mengenai sub pokok bahasan Suhu dan Pengukuran suhu sedangkan untuk pertemuan II membahas mengenai sub pokok bahasan Pemuaian. Langkah-langkah pembelajaran pada siklus I dilaksanakan sesuai dengan Rencana Pelaksanaan Pembelajaran (RPP) I dan Rencana Pelaksanaan Pembelajaran (RPP) II.

Setelah melakukan 2 kali pertemuan, pada pertemuan terakhir untuk siklus I, siswa diberikan tes dalam bentuk ulangan formatif untuk mengetahui penguasaan siswa terhadap materi pembelajaran yang telah diajarkan. Tes yang diberikan ini terdiri dari 9 soal pilihan ganda yang terkait dengan materi suhu dan pemuaian. Soal-soal tes ini sebelumnya telah dianalisis melalui uji validitas, reliabilitas, daya beda serta tingkat kesukarannya.

Hasil penelitian pada siklus 1 dapat

\begin{tabular}{|c|c|c|c|}
\hline No. & $\begin{array}{c}\text { Variabel yang } \\
\text { diamati }\end{array}$ & Jumlah & $\begin{array}{c}\text { Persentase } \\
(\%)\end{array}$ \\
\hline 1. & $\begin{array}{l}\text { Jumlah siswa } \\
\text { peserta tes }\end{array}$ & 35 & 97,22 \\
\hline 2 & Vilai rata-rata siswa & 63,03 & - \\
\hline 3. & $\begin{array}{l}\text { Jumlah siswa yang } \\
\text { telah berhasil } \\
\text { dalam belajar }\end{array}$ & 10 & 28,57 \\
\hline
\end{tabular}
dilihat pada tabel-tabel dibawah ini :

Tabel 1 hasil belajar siswa pada siklus 1
4. Jumlah siswa yang
25
71,42
belum berhasil
dalam belajar

Berdasarkan tabel 1 di atas, dapat diketahui bahwa hasil belajar yang diperoleh siswa pada aspek pengetahuan dalam pelaksanaan tindakan siklus 1 ini masih rendah. Terlihat pada tabel 4.1 dari 35 orang siswa yang mengikuti tes hasil belajar, jumlah siswa yang berhasil 10 orang atau $28,57 \%$ dari jumlah siswa keseluruhan yang nilainya berada di atas Kriteria Ketuntasan Minimun (KKM), yaitu di atas 75. Nilai rata-rata siswa masih rendah yaitu 63,03, hal ini menunjukkan bahwa pelaksanaan proses pembelajaran pada siklus I ini masih benyak terdapat kekurangan dan perlu ditingkatkan pada siklus selanjutnya, yaitu dengan melaksanakan pelaksanaan tindakan pada siklus II.

Tabel 2 Rata-rata aktivitas siswa pada proses pembelajaran siklus 1

\begin{tabular}{ccc} 
Yang diamati & $\begin{array}{c}\text { Persentase } \\
(\%)\end{array}$ & kategori \\
\hline $\begin{array}{l}\text { ata-rata aktivitas } \\
\text { mbelajaran siswa }\end{array}$ & 68,37 & Aktif
\end{tabular}

Adapun kendala-kendala yang dihadapi pada pelaksanaan kegiatan pembelajaran pada siklus I diantaranya:

1). Banyak siswa yang kurang aktif dalam menjawab pertanyaan yang diajukan oleh guru, hal ini disebabkan sebagian besar siswa masih malu untuk menjawab pertanyaan. 2). Banyak siswa yang kurang perhatian saat guru menjelaskan tujuan pembelajaran. 3). Masih banyak siswa yang tidak memperhatikan saat guru menyampaikan kegiatan-kegiatan yang akan dilakukan selama proses pembelajaran. 4). Banyak siswa yang kurang memperhatian saat guru menyampaikan materi pelajaran. 5). Banyak siswa tidak ikut terlibat dalam mengerjakan contoh soal. 6). Hanya sebagian siswa yang menyerahkan kupon sebelum berbicara. 7). Banyak siswa yang kurang memperhatikan saat guru menyampaikan materi selanjutnya. 8). Sebagian siswa tidak mencatat 
tugas yang diberikan oleh guru, hal ini disebabkan karena siswa lain malas untuk mencatat.

Untuk memperbaiki kekurangan kekurangan yang ada pada siklus I dan untuk meningkatkan hasil belajar dan aktivitas siswa, maka perlu dilanjutkan ke siklus II dengan melakukan beberapa perbaikan, yaitu sebagai berikut:

1). Mempertahankan tahapan kegiatan yang baik pada siklus I. 2). Memberikan kesempatan lebih luas bagi siswa untuk menjawab pertanyaan dan mendorong siswa untuk berani menyampaikan pendapat. 3). Guru harus lebih jelas dan tegas lagi dalam menyampaikan tujuan pembelajaran. 4). Guru menjelaskan dengan tepat dan jelas langkah-langkah pembelajaran serta tugas yang harus dikerjakan oleh siswa. 5). Guru harus memperhatikan lagi saat melibatkan siswa mengerjakan contoh soal. 6). Guru harus lebih baik dalam membimbing saat melakukan diskusi. 7). Menegaskan lagi agar siswa menggunakan kuponnya dengan rasa tanggung jawab.

Siklus II

Pelaksanaan Tindakan

Pelaksanaan tindakan yang dilakukan pada siklus II terdiri dari dua kali pertemuan dan satu kali ujian siklus. Pertemuan I membahas mengenai sub pokok bahasan kalor jenis dan kapasitas kalor sedangkan untuk pertemuan II membahas mengenai sub pokok bahasan Perubahan wujud. Langkah-langkah pembelajaran pada siklus II dilaksanakan sesuai dengan Rencana Pelaksanaan Pembelajaran (RPP) I dan Rencana Pelaksanaan Pembelajaran (RPP) II.

Setelah melakukan 2 kali pertemuan, pada pertemuan terakhir untuk siklus II, siswa diberikan tes dalam bentuk ulangan formatif untuk mengetahui penguasaan siswa terhadap materi pembelajaran yang telah diajarkan. Tes yang diberikan ini terdiri dari 8 soal pilihan ganda yang terkait dengan materi kalor dan perubahan wujud. Hasil penelitian pada siklus II dapat dilihat pada tabel-tabel dibawah ini :
Tabel 3. Hasil belajar pada siklus II

\begin{tabular}{|c|c|c|c|}
\hline No & $\begin{array}{c}\text { Variabel yang } \\
\text { diamati }\end{array}$ & Jumlah & $\begin{array}{c}\text { Persentase } \\
(\%)\end{array}$ \\
\hline 1 & $\begin{array}{l}\text { Jumlah siswa } \\
\text { peserta tes }\end{array}$ & 35 & 97,22 \\
\hline 2 & $\begin{array}{l}\text { Nilai rata-rata } \\
\text { siswa }\end{array}$ & 70,00 & - \\
\hline 3 & $\begin{array}{l}\text { Jumlah siswa } \\
\text { yang telah } \\
\text { berhasil dalam } \\
\text { belajar }\end{array}$ & 20 & 57,14 \\
\hline 4 & $\begin{array}{l}\text { Jumlah siswa } \\
\text { yang belum } \\
\text { berhasil dalam } \\
\text { belajar }\end{array}$ & 15 & 42,85 \\
\hline
\end{tabular}

Dari tabel hasil belajar di atas, dapat diketahui bahwa pelaksanaan pada siklus II sudah mengalami peningkatan dari siklus I. Ini dapat dilihat dari hasil belajar siklus II yang diikuti oleh 35 siswa. Nilai rata-rata yang diperoleh meningkat dari 63,03 pada siklus I menjadi 70,00 pada siklus II. Jumlah siswa yang memperoleh nilai $\geq 75$ sebanyak 20 orang. Hal ini mengindikasikan bahwa keberhasilan mencapai $57,14 \%$ dan siswa yang belum berhasil $42,85 \%$ maka tindakan dilanjutkan pada siklus III.

Tabel 4. Rata-rata aktivitas siswa pada proses pembelajaran siklus II

\begin{tabular}{ccc}
\hline \multicolumn{1}{c}{ Yang diamati } & $\begin{array}{c}\text { Persentase } \\
(\%)\end{array}$ & Kategori \\
\hline $\begin{array}{l}\text { Rata-rata aktivitas } \\
\text { pembelajaran siswa }\end{array}$ & 71,75 & Aktif \\
\hline
\end{tabular}

Adapun kendala-kendala yang dihadapi pada pelaksanaan kegiatan pembelajaran pada siklus II diantaranya:

1). Masih Banyak siswa yang kurang aktif menjawab pertanyaan yang diajukan oleh guru pada saat awal pembelajaran. 2). Masih ada siswa yang tidak mengerjakan contoh soal. 3). Masih ada siswa yang tidak menyerahkan kupon sebelum berbicara. Dengan kata lain masih malu untuk berbicara atau mengemukakan pendapatnya. 4). Masih banyak siswa yang tidak mencatat tugas yang diberikan oleh guru.

Untuk memperbaiki kekurangan kekurangan yang ada pada siklus II dan untuk 
meningkatkan hasil belajar dan aktivitas siswa, maka perlu dilanjutkan ke siklus III dengan melakukan beberapa perbaikan, yaitu sebagai berikut:

1). Mempertahankan tahapan kegiatan yang baik pada siklus II. 2). Memakai intonasi suara dalam menjelaskan. 3). Memberikan kesempatan siswa untuk menjawab pertanyaan yang diberikan. 4). Guru harus menegaskan lagi agar siswa menggunakan kupon belajaranya. 5). Membimbing diskusi dengan baik.

Siklus III

Pelaksanaan Tindakan

Siklus III merupakan kegiatan lanjutan dan perbaikan dari siklus I dan II. Proses pembelajaran dilakukan berdasarkan dari hasil refleksi tindakan pada siklus II, yang terdapat beberapa kegiatan yang belum terlaksana dengan baik. Pelaksanaan tindakan dilaksanakan dua kali pertemuan dan satu kali tes hasil belajar. Pertemuan I membahas mengenai sub pokok bahasan perpindahan kalor sedangkan untuk pertemuan II membahas mengenai sub pokok bahasan Asas Black. Langkah-langkah pembelajaran pada siklus III dilaksanakan sesuai dengan Rencana Pelaksanaan Pembelajaran (RPP) V dan Rencana Pelaksanaan Pembelajaran (RPP) VI.

Sama halnya dengan siklus I dan Siklus II, pada siklus III setelah melakukan 2 kali pertemuan juga dilaksanakan tes formatif dengan tujuan untuk mengetahui tingkat penguasaan materi pada siklus III. Jumlah soal dalam tes ini lebih banyak jika dibandingkan dengan jumlah soal pada tes formatif yang diadakan pada siklus I dan II yaitu sebanyak 15 soal pilihan ganda terkait dengan materi perpindahan kalor dan Asas Black. Hasil penelitian pada siklus III dapat dilihat pada tabel-tabel dibawah ini :

Tabel 5. Hasil belajar pada sikus III

\begin{tabular}{llcc}
\hline No & $\begin{array}{c}\text { Variabel yang } \\
\text { diamati }\end{array}$ & jumlah & $\begin{array}{c}\text { Persentase } \\
(\%)\end{array}$ \\
\hline 1 & $\begin{array}{l}\text { Jumlah siswa } \\
\text { peserta tes }\end{array}$ & 34 & 94,44 \\
2 & $\begin{array}{l}\text { Nilai rata-rata } \\
\text { siswa }\end{array}$ & 76,86 & - \\
3 & $\begin{array}{l}\text { Jumlah siswa } \\
\text { yang telah } \\
\text { berhasil dalam }\end{array}$ & 21 & 61,76 \\
\hline
\end{tabular}

\begin{tabular}{llll}
\hline & belajar & & \\
Jumlah siswa & 13 & 38,23 \\
yang belum \\
berhasil dalam \\
belajar
\end{tabular}

Dari tabel hasil belajar di atas, dapat diketahui bahwa pelaksanaan pada siklus III sudah mengalami peningkatan dari siklus II. Ini dapat dilihat dari hasil belajar siklus III yang diikuti oleh 34 siswa. Nilai rata-rata yang diperoleh meningkat dari 70,00 pada siklus II menjadi 76,86 pada siklus III yang sekaligus menunjukkan bahwa nilai rata-rata siswa telah melebihi indikator keberhasilan untuk penelitian yaitu sebesar 75\%. Angka keberhasilan ini menunjukkan bahwa tindakan yang dilakukan dapat dikatakan berhasil.

Tabel 6. Rata-rata aktivitas siswa pada proses pembelajaran siklus III

\begin{tabular}{ccc}
\hline Yang diamati & $\begin{array}{c}\text { Persentase } \\
(\%)\end{array}$ & Kategori \\
\hline $\begin{array}{l}\text { Rata-rata aktivitas } \\
\text { pembelajaran siswa }\end{array}$ & 74,06 & Aktif \\
\hline
\end{tabular}

\section{Simpulan dan Saran}

Simpulan

Simpulan dapat bersifat generalisasi temuan sesuai permasalahan penelitian, dapat pula berupa rekomendatif untuk langkah selanjutnya. Berdasarkan hasil penelitian tindakan kelas yang telah dilaksanakan dengan menerapkan model pembelajaran kooperatif tipe Time Token dapat meningkatkan aktivitas siswa, hal ini dapat dilihat dari rata-rata presentase aktivitas siswa pada siklus I adalah $68,37 \%$, siklus II 71,75\%, dan siklus III $74,06 \%$. Adapun aktivitas - aktivitas siswa yang meningkat diantaranya adalah : (a) siswa yang menjawab pertanyaan apersepsi yang diajukan oleh guru (b) Siswa yang menggunakan kupon berbicara untuk menyelesaikan lembar tugas diskusi kelompok (c) siswa yang meminta kembali kupon belajar. Aktivitas ini dapat meningkat karena aktivitas yang dilakukan oleh guru selalu diperbaiki berdasarkan kendala dan solusi yang ada pada setiap siklus. Peningkatan nilai rata-rata hasil belajar pada aspek pengetahuan dari siklus I 
adalah 63,03 dengan jumlah siswa yang berhasil sebanyak 10 orang $(28,57 \%)$, siklus II 70,00 dengan jumlah siswa yang berhasil sebanyak 20 orang $(57,14 \%)$ dan untuk siklus III 76,86 dengan jumlah siswa yang berhasil sebanyak 21 orang $(61,76 \%)$ tetapi ada 13 orang $(38,23 \%)$ yang belum berhasil mencapai nilai KKM. Berdasarkan hasil penelitian, dapat disimpulkan bahwa pelaksanaan pembelajaran dengan menerapkan model pembelajaran kooperatif tipe Time Token dapat meningkatkan aktivitas dan hasil belajar fisika siswa pada materi suhu dan kalor di SMA Negeri 3 Muaro Jambi.

Saran

Berdasarkan kesimpulan yang
diperoleh di atas serta untuk lebih meningkatkan hasil belajar fisika siswa, maka penulis menyarankan beberapa hal:

1). Guru fisika dapat menggunakan model pembelajaran kooperatif tipe Time Token untuk meningkatkan aktivitas siswa dan hasil belajar fisika siswa, terutama pada materi suhu dan kalor. 2). Karena penelitian ini hanya dilakukan pada materi suhu dan kalor, maka diharapkan penelitian yang serupa dapat pula dilaksanakan pada materi yang lain.

3). Penelitian ini masih terbatas pada model pembelajaran kooperatif tipe Time Token, maka diharapkan penelitian yang serupa dapat pula dilaksanakan dengan menggunakan model pembelajaran lain.

\section{Daftar Pustaka}

Arikunto, S. (2009). Dasar-dasar Evaluasi Pendidikan. Jakarta: Bumi Aksara. . (2013). Prosedur Penelitian Suatu

Pendekatan Praktek. Jakarta: PT. Rineka Cipta.

Huda, Miftahul. (2014). Model-Model Belajar Dan Pembelajaran.Yogyakarta: Pustaka Pelajar

Isjoni. (2012). Pembelajaran Kooperatif. Yogyakarta: Pustaka Pelajar

Purwanto. (2013). Evaluasi Hasil Belajar. Yogyakarta: Pustaka Pelajar.

Shohimin, Aris. (2014). 68 Model Pembelajaran Inovatif Dalam Kurikulum 2013. Yogyakarta: Ar-Ruzz Media

Sudjana. (2002). Metoda Statistika. Bandung: Tarsito

Sudjana, Nana. (2006). Dasar - dasar Proses Belajar Mengajar. Bandung: Sinar Baru Algesindo

Sugiyono. (2008). Metode Penelitian Pendidikan Pendekatan Kuantitatif, Kualitatif Dan R\&D. Bandung: Alfabeta 